\title{
Optimization of bacteriocin production by Lactobacillus plantarum YJG, isolated from the mucosa of the gut of healthy chickens
}

\author{
Bing Han, Zhanqiao Yu, Baosheng Liu, Qingshan Ma and Rijun Zhang*
}

Laboratory of Feed Biotechnology, State Key Laboratory of Animal Nutrition, College of Animal Science and Technology, China Agricultural University No. 2 Yuanmingyuan West Road, Haidian District, Beijing 100193, China.

Accepted 7 April, 2011

\begin{abstract}
The objective was to develop an optimal, albeit low-cost medium for bacteriocin production, thereby facilitating industrial production. Soybean meal and peptide, two low-cost nitrogen sources often applied in industrial fermentation, were used to replace their expensive counterparts in De Man Rogosa and Sharpe (MRS). Two factors were first chosen from the 11 considered in the Plankett-Burman (PB) design. Then, the path of steepest ascent and central composite design (CCD) were used to approach the optimum region of the response and determine the maximum activity of the bacteriocin. Optimal concentration of glucose $(36.3 \mathrm{~g} / \mathrm{l})$ and $\mathrm{NaCl}(1.41 \mathrm{~g} / \mathrm{l})$ stimulated the production of bacteriocins. And the optimal equation was then verified by $50 \mathrm{~L}$ fermentor. Under optimized conditions, Lactobacillus plantarum YJG produced a 1.4 fold higher production of bacteriocin than the common MRS, with $40.6 \%$ cost savings relative to non-optimized conditions.
\end{abstract}

Key words: Lactobacillus plantarum YJG, bacteriocin, response surface methodology, central composite design, optimization.

\section{INTRODUCTION}

Bacteriocins, ribosomally synthesized antibacterial peptides, are regarded as potential alternatives to conventional antimicrobials (Klaenhammer, 1988; Cleveland et al., 2001). For example, the bacteriocin produced by Lactobacillus plantarum YJG in this study inhibited some strains of pathogenic bacteria, including Staphylococcus aureus and Salmonella typhi (Integrated Vocational Development Centre, IVDC, Beijing, China).

Bacteriocins were one family of microbial defense system, which meant they may prohibit the invasion of other strains or the change of the environment, both biotic and abiotic (Riley and Wertz, 2002). Now many kinds of bacteriocins have been found from different bacteria; however, only one bacteriocin named nisin has been really applicated. Early in 1969, WHO announced that nisin was a kind of food preservative with safety and

${ }^{*}$ Corresponding author. E-mail: feedbiotech@yahoo.com. Tel: +8610-62731208. Fax: +8610-87969550. high efficiency, and after that, in 1983 FDA declared that nisin was general recognized as safe. Except nisin, most of other bacteriocins are focused on isolation and purification on a laboratory scale, with little or no consideration to industrial-scale production or being applicated to human life.

Production of bacteriocins can be influenced by many things, including medium composition(Zhou et al., 2008), environmental factors (Leal-Sánchez et al., 2002; Motta and Brandelli, 2008), and other growth conditions. De Man Rogosa and Sharpe (MRS) is the standard culture media for lactic acid bacteria (LAB), but its high cost limits its suitability for industrial-scale production. MRS has ever been used for large scale fermentation, while the purpose was to produce something, like some enzymes, or other metabolin (Lu et al., 2003; Hummel et al., 1983). Studies lowering the cost of culture media have been published (Dominguez et al., 2007; Trinetta et al., 2008; Wiese et al., 2010), not referring to industrial fermentation.

Response surface methodology is a statistical method 
to verify optimal conditions of factors for a required response. This technique was successfully applied in many fields of biotechnology, including bacteriocin production (Dominguez et al., 2007; Wiese et al., 2010; Delgado et al., 2007; Anthony et al., 2009). The objective of the present study was to increase the efficiency of bacteriocin production and reduce the cost of fermentation, thereby increasing the viability of industrialscale production.

\section{MATERIALS AND METHODS}

\section{Bacterial strains and media}

The producer strain used in this work was L. plantarum YJG, was previously isolated from the mucosa of the gut of healthy chickens (Zhu et al., 2009). The indicator strain was S. aureus IVDC C56005 used for the bacteriocin activity assay. The MRS broth and the Beef extract-Peptone-Yeast extract (BPY) (Xie et al., 2009) broth, both containing $20 \%(\mathrm{v} / \mathrm{v})$ glycerol, were separately used as the stock culture for the producer strain and indicator organism at $-20^{\circ} \mathrm{C}$, respectively. Bacterial stocks were propagated twice before expectation. Strong colony was first picked out and inoculated in sterile liquid MRS, and the inoculum was cultured at $37^{\circ} \mathrm{C}$ statically for $24 \mathrm{~h}$, then the initial $\mathrm{pH}$ was adjusted to 7.0 with $1 \mathrm{M}$ sterile $\mathrm{NaOH}$. The second operation was repeated in the same way. The cells biomass reached $10^{9} \mathrm{cfu} / \mathrm{ml}$.

\section{Selection of optimal sources of nitrogen and carbon substrates for bacteriocin production}

There are three organic nitrogen sources in MRS medium, including beef extract, soybean peptone and yeast extract. Due to the high cost of the first two nitrogen sources, several nitrogen sources, commonly used in industry, namely peptide powder (products from the fermentation of soybean), soybean meal (by-products from soybean oil extraction), urea, and $\left(\mathrm{NH}_{4}\right)_{2} \mathrm{SO}_{4}$ were studied. The unit of the soybean meal should be less than $0.2 \mathrm{~mm}$. The yeast extract was as a control group. Corn flour $(<0.2 \mathrm{~mm})$ and molasses were chosen as the carbon sources. Both $\mathrm{KH}_{2} \mathrm{PO}_{4}$ and $\mathrm{CaCO}_{3}$ were added to regulate the $\mathrm{pH}$ of the culture media, $\mathrm{NaCl}$ was also in consideration, whereas the remaining ingredients of MRS were retained.

\section{Determination of the levels of the $\mathbf{1 1}$ factors (Plankett-Burman design)}

The levels of $\mathrm{NaCl}$ was determind by single-factor experiment (Table 1a), while $\mathrm{CaCO} 3, \mathrm{~K} 2 \mathrm{HPO} 4$ and $\mathrm{KH} 2 \mathrm{PO} 4$ were determined by the orthogonal experimental design (Table 1b).

\section{Cultivation}

Aliquot $(2 \mathrm{ml})$ inoculum was added to the $100 \mathrm{ml}$ sterile improved MRS broth for optimization. The initial $\mathrm{pH}$ of every treatment above (including in PB, the steepest ascent and CCD) was adjusted to 7.0 with $1 \mathrm{M} \mathrm{NaOH}$. The media inoculated was cultured at $37^{\circ} \mathrm{C}$ for 44 to $48 \mathrm{~h}$ without shaking. Aliquots $(1 \mathrm{ml})$ were centrifuged at $12000 \mathrm{~g}$ for $10 \mathrm{~min}$. The supernatants were filter-sterilized using $0.22 \mu \mathrm{m}$ microfilters (Pall Corparation, Massachusetts, USA) and adjusted to
Table 1a. The single-factor experiment ( $\mathrm{NaCl})$.

\begin{tabular}{ccc}
\hline Treatment & $\begin{array}{c}\text { Concentration } \\
\text { of } \mathbf{~ N a C l ~}(\mathbf{g} / \mathbf{l})\end{array}$ & Initial pH \\
\hline 1 & 0 & 6.0 \\
2 & 0.2 & 6.0 \\
3 & 2.0 & 6.0 \\
4 & 20 & 6.0 \\
5 & 0 & 6.5 \\
6 & 0.2 & 6.5 \\
7 & 2.0 & 6.5 \\
8 & 20 & 6.5 \\
9 & 0 & 7.0 \\
10 & 0.2 & 7.0 \\
11 & 2.0 & 7.0 \\
12 & 20 & 7.0 \\
\hline
\end{tabular}

Four concentrations of $\mathrm{NaCl}$ at different initial $\mathrm{pH}$ value were considered to find out the proper one.

Table 1b. The orthogonal experimental design.

\begin{tabular}{cccc}
\hline Treatment & $\mathrm{CaCO}_{3}(\mathrm{~g} / \mathrm{l})$ & $\mathrm{K}_{2} \mathrm{HPO}_{4}(\mathrm{~g} / \mathrm{I})$ & $\mathrm{KH}_{2} \mathrm{PO}_{4}(\mathrm{~g} / \mathrm{l})$ \\
\hline x1 & 5 & 1.0 & 1.0 \\
x2 & 5 & 2.0 & 1.5 \\
x3 & 5 & 3.0 & 2.0 \\
x4 & 10 & 1.0 & 1.0 \\
x5 & 10 & 2.0 & 1.5 \\
x6 & 10 & 3.0 & 2.0 \\
x7 & 15 & 1.0 & 1.0 \\
x8 & 15 & 2.0 & 1.5 \\
x9 & 15 & 3.0 & 2.0 \\
\hline
\end{tabular}

Three salts $\left(\mathrm{CaCO}_{3}, \mathrm{~K}_{2} \mathrm{HPO}_{4}, \mathrm{KH}_{2} \mathrm{PO}_{4}\right)$ were referred in this experiment to find the proper concentration of each salt in $\mathrm{PB}$ design.

$\mathrm{pH} 5.0$ with $1 \mathrm{M}$ sterile $\mathrm{NaOH}$ for bacteriocin activity assay.

\section{Bacteriocin activity assay}

The bacteriocin activity was detected by agar disk diffusion assay. An aliquot of $200 \mu \mathrm{l}$ cell-free supernatant was added to Oxford cup on the plates, and incubated at $30^{\circ} \mathrm{C}$. The bacteriocin bioactivity was indicated using the square of the inhibition area $\left(\mathrm{mm}^{2}\right)$ of the indicator bacteria (Delgado et al., 2007; Xie et al., 2009).

\section{Experimental designs}

A Plackett-Burman (PB) design was used to determine the most influential of the 11 factors for bacteriocin production and the low and high level were shown (Table 1c). The PB design replicated for three times (each time included 12 treatments). This method is often used for an experiment involving many factors, the significance of which is not certain to the response variable. 
Table 1c. The coded number and the two levels of the factors in Plackett-Burman design.

\begin{tabular}{|c|c|c|c|c|c|c|c|}
\hline \multirow{2}{*}{ Factors } & \multirow{2}{*}{ Number } & \multicolumn{2}{|c|}{ Coded level } & \multirow{2}{*}{ Factors } & \multirow{2}{*}{ Number } & \multicolumn{2}{|c|}{ Coded level } \\
\hline & & -1 & 1 & & & -1 & 1 \\
\hline Glucose $(g / l)$ & $A$ & 30 & 45 & $\mathrm{NaCl}(\mathrm{g} / \mathrm{l})$ & $G$ & 1 & 1.5 \\
\hline soybean peptone (g/l) & B & 15 & 25 & $\mathrm{~K}_{2} \mathrm{HPO}_{4}(\mathrm{~g} / \mathrm{l})$ & $\mathrm{H}$ & 2 & 3 \\
\hline yeast extract $(\mathrm{g} / \mathrm{l})$ & $\mathrm{C}$ & 10 & 20 & $\mathrm{KH}_{2} \mathrm{PO}_{4}(\mathrm{~g} / \mathrm{l})$ & $\mathrm{J}$ & 1.5 & 2.5 \\
\hline peptide powder (g/l) & $\mathrm{D}$ & 20 & 30 & Culture temperature $\left({ }^{\circ} \mathrm{C}\right)$ & $\mathrm{K}$ & 30 & 37 \\
\hline Tween 80 (g/l) & E & 0.1 & 0.15 & Inoculum (\%) & L & 2.0 & 3.0 \\
\hline $\mathrm{CaCO}_{3}(\mathrm{~g} / \mathrm{l})$ & $\mathrm{F}$ & 1 & 1.5 & & & & \\
\hline
\end{tabular}

The eleven factors were expressed by capital letters A to $G$, with each factor having two levels.

Table 2. The level of the two factors in central composite design (CCD).

\begin{tabular}{lcccccc}
\hline \multirow{2}{*}{ Variable } & \multirow{2}{*}{ Symbol } & \multicolumn{5}{c}{ Coded level } \\
\cline { 3 - 7 } & & $\mathbf{- 1 . 4 1 4}$ & $\mathbf{- 1}$ & $\mathbf{0}$ & $\mathbf{1}$ & $\mathbf{1 . 4 1 4}$ \\
\hline Glucose $(\mathrm{g} / \mathrm{l})$ & $\mathrm{A}$ & 1.72 & 10 & 30 & 50 & 58.28 \\
$\mathrm{NaCl}(\mathrm{g} / \mathrm{l})$ & $\mathrm{G}$ & 0.086 & 0.5 & 1.5 & 2.5 & 2.914 \\
\hline
\end{tabular}

Each variable has five levels.

In this design, significance is determined by comparing the difference of two levels. Relative to a single-factor study, a PB design can be conducted more quickly and easily. Then the path of steepest ascent was used to approach the central point of the response.

To determine the response surface in the optimum region, a central composite design, was used to study the interaction of $\mathrm{x} 1$ and $x 2$ on the bacteriocin production and Table 2 indicated the levels of both factors. The two variables were coded at five levels $( \pm \alpha, \pm 1,0)$. Actually, this design was made up of a $2^{2}$ factorial design with its four points augmented with five central points (both factors at 0 level). The axial distance was chosen to be 1.414 to make the design orthogonal. The CCD design included 13 treatments, which were all carried out at $37^{\circ} \mathrm{C}$ without shaking. For two factors the equation model was:

$Y=b_{0}+b_{1} x_{1}+b_{2} x_{2}+b_{12} x_{1} x_{2}+b_{11} x_{1}^{2}+b_{22} x_{2}^{2}$

Where $Y$, predicted response, $b_{0}$, intercept; $b_{1}, b_{2}$, linear coefficients; $b_{11}, b_{22}$, squared coefficients and $b_{12}$, interaction coefficients.

The results were analyzed by Design-Expert 7.1.3 (StatEase, Inc., Minneapolis, MN, USA) and SPSS 10.0 (SPSS Corp., Chicago, IL, USA). In addition, ANOVA was used to assess the statistical variables for optimization of fermentation medium, with an F-test used to verify the statistical significance. The coefficient of determination $\left(R^{2}\right)$ was employed for the quality of the fit of the polynomial model equation.

\section{Validation of the model}

To verify the accuracy of the model and the optimum results, the experiment was conducted on the base of an optimum medium with a $50 \mathrm{~L}$ fermentor. The experiment was repeated three times.

\section{RESULTS}

\section{Determination of the levels of some factors (Plankett- Burman design)}

Levels of $\mathrm{CaCO}_{3}, \mathrm{~K}_{2} \mathrm{HPO}_{4}, \mathrm{KH}_{2} \mathrm{PO}_{4}$ were determined by an orthogonal experimental design, and the result was as follows (as shown in Figure 1, x1-x9), whereas levels of $\mathrm{NaCl}$ and Tween 80 were determined by single-factor experiments and the result was shown in Figure 1 ( $x 1$ $x 9)$.

\section{Selection of the best nitrogen and carbon source substrates}

Bacteriocin activity and biomass were tested on different nitrogen and carbon substrates. Glucose was remained the best carbon source; Meanwhile, yeast extract, soybean meal and peptide were all chosen as the proper nitrogen sources for the high bacteriocin production and biomass (Figure 2).

\section{Response surface methodology}

\section{Plackett-Burman design}

Variables were separated into two groups: variables $(A, L$, $K)$ had the negative effect on bacteriocin production, whereas the other ones (factors except $A, L, K$ ) had the positive impact (shown in Figure 3 ). Two variables, glucose and $\mathrm{NaCl}$ were identified (ANOVA) as the most important factors (data not shown).

\section{The path of steepest ascent}

According to the two significant factors on bacteriocin production, A (Glucose) had a negative effect, whereas the effects of $\mathrm{G}(\mathrm{NaCl})$ were positive (Figure 3); as a result, the design of the two factors should have a positive consequence for bacteriocin production. The outcome of changing directions of these two factors was 


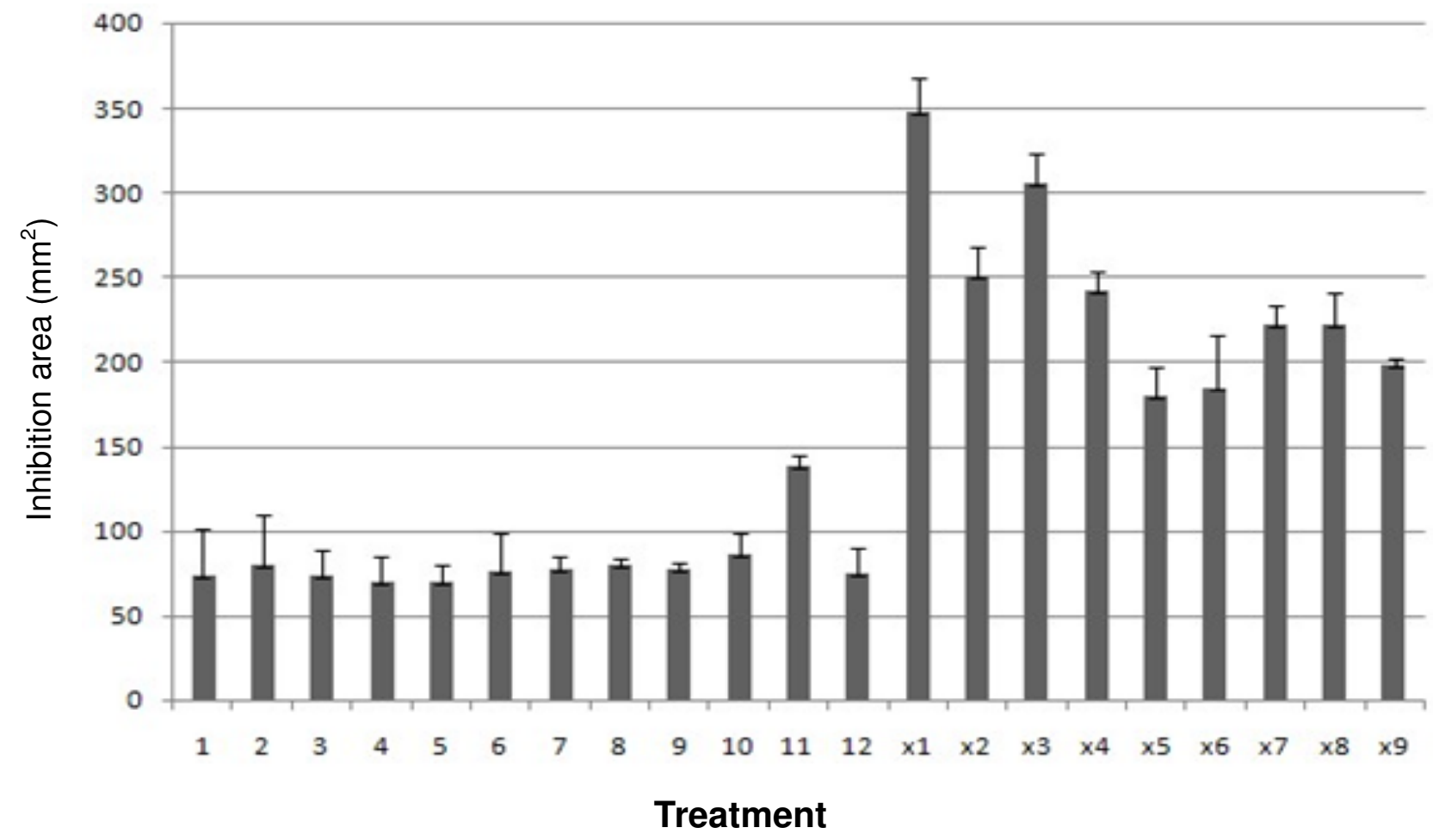

Figure 1. Different salt on bacteriocin production- $\mathrm{NaCl}$ on bacteriocin production(1-10); The orthogonal experimental design of $\mathrm{CaCO}_{3}, \mathrm{~K}_{2} \mathrm{HPO}_{4}, \mathrm{KH}_{2} \mathrm{PO}_{4}$ on bacteriocin production (x1-x9).

shown in Table 3. Apparently, the optimum medium was the third treatment.

\section{Central composite design and optimization of the medium}

The level of the central point was determined through the path of the steepest ascent. The effects of levels of the two variables in the central composite design are shown (Table 2), including the experimental and predicted values of bacteriocin activity (Table 4). Based on the data analyzed by design-expert 7.1.3, the model was in accordance with a second-order polynomial function, with the following form:

\section{$Y=439.69+82.16 \quad A-14.46 \quad G-21.71 \quad A G-133.38 A^{2}-$ $123.87 \mathrm{G}^{2}$

where $Y$ is bacteriocin activity (inhibition area, $\mathrm{mm}^{2}$ ), $\mathrm{A}$ is Glucose $(\mathrm{g} / \mathrm{l})$; and $\mathrm{G}$ is $\mathrm{NaCl}(\mathrm{g} / \mathrm{l})$. The statistical significance of the model equqtion was evaluated by the ANOVA; since, $R^{2}=0.9404\left(R^{2}>0.75\right.$ indicated the aptness of the model), $94.04 \%$ of the variability could be explained by the mode. The levels of the impact of the A, $A^{2}, G^{2}$ on the value of $Y$ were significant. Therefore, the quadratic coefficient had a significant effect on the response, whereas the coefficient of AG was not significant. Consequently, the interaction of glucose and $\mathrm{NaCl}$ had a small influence on bacteriocin production. Since both of the quadratic coefficients in equation (2) were negative, the parabola opened downwards and had a maximum point (Figure 4a).

\section{Validation of the model}

By derivation of equation (2), the maximum point of the response model could be calculated; that was $36.3 \mathrm{~g} / \mathrm{l}$ (glucose) and $1.41 \mathrm{~g} / \mathrm{l}(\mathrm{NaCl})$. When the concentration of gulcose was over $36.3 \mathrm{~g} / \mathrm{l}$, the bacteriocin production was reduced (Figure 4). Furthermore, the model predicted the maximum response of $465.16 \mathrm{~mm}^{2}$. To validate the maximum point, experiments using the best concentration of glucose and $\mathrm{NaCl}$ were performed. Under these conditions, the mean value of bacteriocin activity was $519.84 \mathrm{~mm}^{2}$, which was close to the predicted value. Therefore, the response model was appropriate for the expected, and the bacteriocin activity was improved by 1.4 fold relative to that using conventional MRS. 

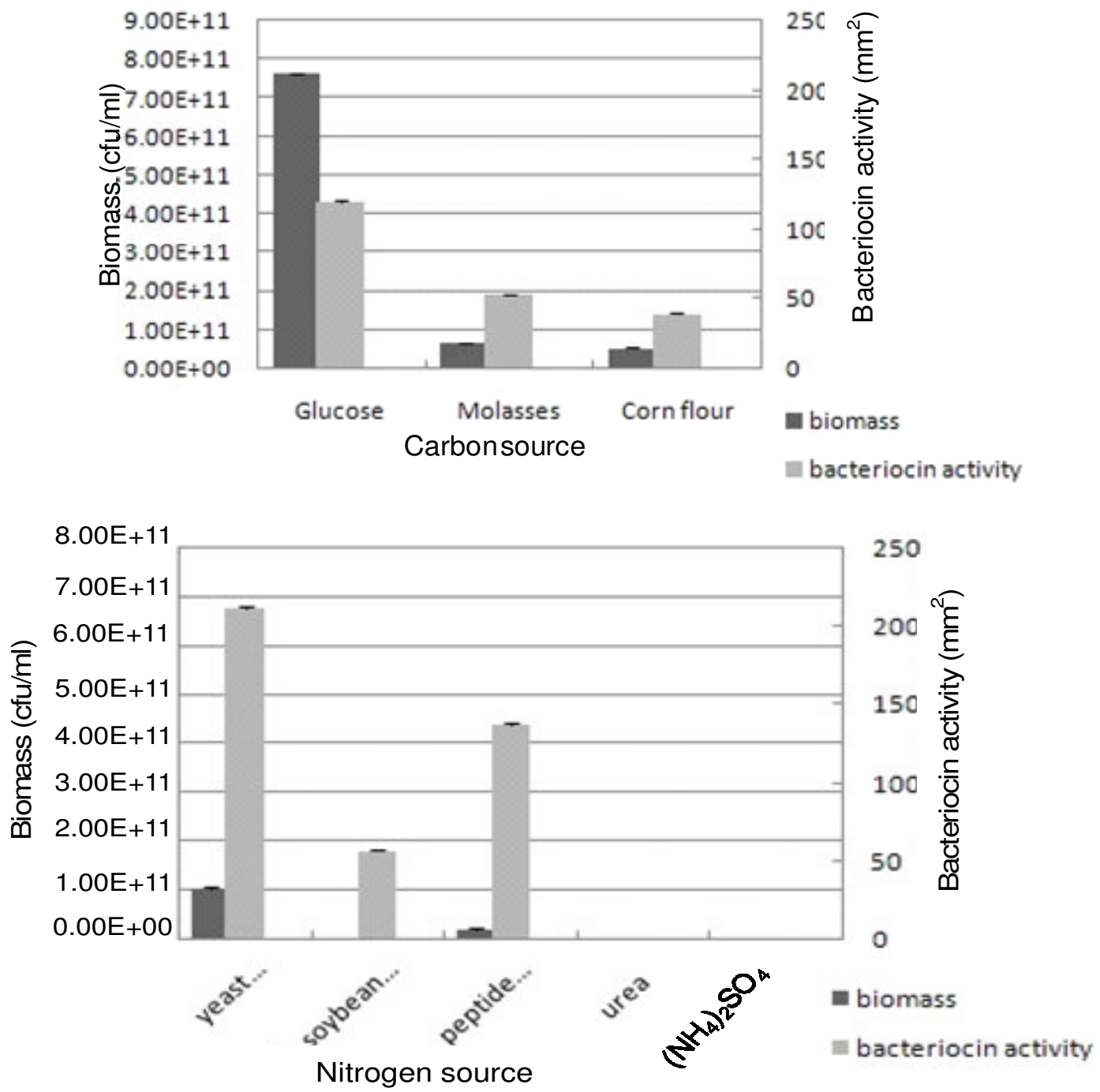

Bacteriocin activity/biomass

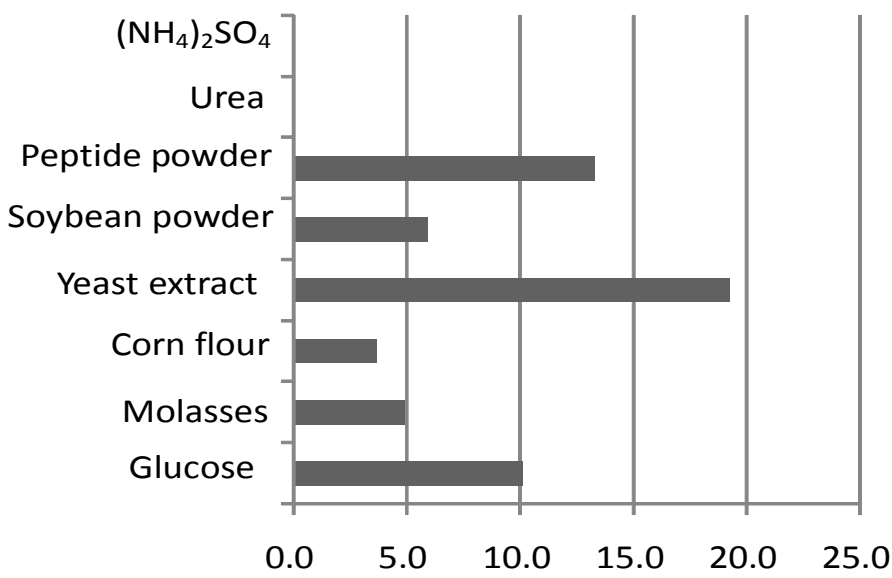

bacteriocin

activity/log(biomass)

Figure 2. The effects of different nitrogen sources and carbon sources on the bacteriocin production and biomass. Different carbon sources experiment was implemented when every treatment was the same (initial $\mathrm{pH} 6.5,37^{\circ} \mathrm{C}$, without shaking, the ingredients of MRS except carbon sources); The nitrogen sources experiment was tried out the same as the carbon sources (the same conditions including culture conditions and the ingredients of MRS except nitrogen sources). 


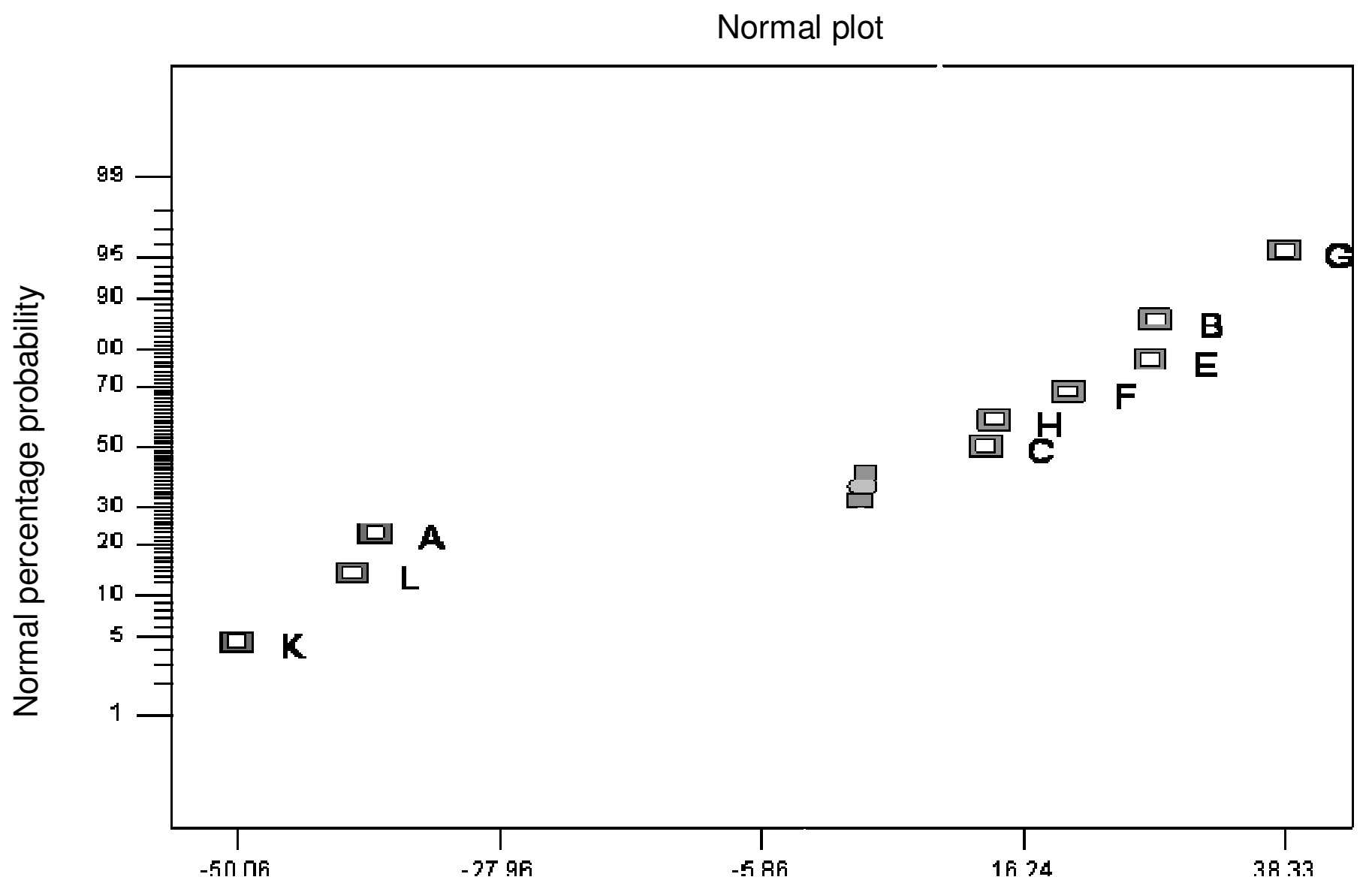

\section{Standard effect}

Figure 3. The influence of the factors on the production of bacteriocin $s$ by PB design. From this figure, it was concluded that $A$, $L$, $K$ showed the negative effects on bacteriocin production; Meanwhile, the other factors showed positive.

Table 3. The path of steepest ascent and the value of the response variable.

\begin{tabular}{cccc}
\hline Run no. & Glucose $(\mathbf{g} / \mathbf{l})$ & $\mathbf{N a C l}(\mathbf{g} / \mathbf{l})$ & Bacteriocin activity $\left(\mathbf{m m}^{2}\right)$ \\
\hline 1 & 40 & 0.5 & $378.79 \mathrm{ab}$ \\
2 & 35 & 1.0 & $369.65 \mathrm{~b}$ \\
3 & 30 & 1.5 & $442.17 \mathrm{a}$ \\
4 & 25 & 2.0 & $322.43 \mathrm{bc}$ \\
5 & 20 & 2.5 & $266.73 \mathrm{~cd}$ \\
6 & 15 & 3.0 & $246.86 \mathrm{~d}$ \\
7 & 10 & 3.5 & $161.28 \mathrm{e}$ \\
8 & 5 & 4.0 & $66.44 \mathrm{f}$ \\
\hline
\end{tabular}

The data of bacteriocin activity was analysed by multiple comparison, and the lowercase letters stand for the significance between the groups. The third group, not the first group, was chosen as the level of the central point of CCD, because of the cost problem.

\section{The calculation of fermentation cost}

The cost of conventional MRS and optimal MRS was separately calculated (according to the prices in our country). Both of the cost of salt addicted to the medium was almost the same. The main difference was the cost 
Table 4. The design and the result of CCD.

\begin{tabular}{cccccc}
\hline \multirow{2}{*}{ Run no. } & \multirow{2}{*}{$\mathbf{A}(\mathbf{g} / \mathbf{l})$} & $\mathbf{G}(\mathbf{g} / \mathbf{l})$ & \multicolumn{2}{c}{${\text { Bacteriocin activity }\left(\mathbf{m m}^{2}\right)}^{\mathbf{2}}$} & Bacteriocin activity/Biomass $^{\mathbf{b}}$ \\
\cline { 4 - 6 } & -1 & -1 & 117.29 & 93.03 & \\
\hline 1 & 1 & -1 & 251.75 & 300.76 & 20.22 \\
2 & -1 & 1 & 166.41 & 107.53 & 3.93 \\
3 & 1 & 1 & 214.13 & 228.43 & 21.69 \\
4 & -1.414 & 0 & 0.00 & 56.74 & 0 \\
5 & 1.414 & 0 & 336.11 & 289.11 & 28.16 \\
6 & 0 & -1.414 & 232.05 & 212.40 & 26.73 \\
7 & 0 & 1.414 & 142.09 & 171.50 & 14.30 \\
8 & 0 & 0 & 466.56 & 439.69 & 42.77 \\
9 & 0 & 0 & 412.09 & 439.69 & 37.83 \\
10 & 0 & 0 & 408.04 & 439.69 & 37.50 \\
11 & 0 & 0 & 445.21 & 439.69 & 40.85 \\
12 & 0 & 0 & 439.60 & 439.69 & 40.32 \\
13 & 0
\end{tabular}

${ }^{a}$ means the measured value. ${ }^{b}$ means the specific activity, and the denominator was actually the log 10 of biomass.

of the nitrogen sources. The cost of substrates was reduced by $57.9 \%$, but considering the amount of glucose, the cost of optimal medium was reduced by about $40.6 \%$.

\section{DISCUSSION}

Response surface methodology has been successfully used in many studies for optimization of bacteriocin production (Delgado et al., 2007; Cladera-Olivera et al., 2004; Li et al., 2002). However, since factors varied among different strains, this work differed previous studies (Delgado et al., 2007; Cladera-Olivera et al., 2004; Li et al., 2002) in choosing factors before RSM.

Effects of physical factors on bacteriocin production, including temperature and $\mathrm{pH}$ (Delgado et al., 2007) were recently studied. The composition of the medium was also shown to have an important role in bacteriocin production (Li et al., 2002). However, studies to reduce the cost of the medium have only been recently conducted (Dominguez et al., 2007). In the present study, some nitrogen sources in MRS were replaced to reduce costs. However, some the nitrogen substrates, could not be used by L. plantarum YJG, such as urea (Figure 2), perhaps due to lack of required enzymes. It proved $L$. plantarum YJG could not grow well only with inorganic nitrogen sources possibly for absence in vitamins and DNA precursors, which was rich in yeast extract.

Low bacteriocin production was caused when using the corn flour as carbon source (Figure 2), perhaps because the bacteriocins were adsorbed to the surface of the corn. Since both molasses and corn flour reduced biomass, we inferred that the bacteria could not make good use of polysaccharides, although monosaccharide were readily utilized. From Figure 4, it could be concluded that the concentration of glucose over $3.63 \mathrm{~g} / \mathrm{l}$ could possibly inhibit the bacteriocin.

Tween 80 used in Plankett-Burman design did not significantly affect bacteriocin production, similar to reports for other bacteriocins (Trinetta et al., 2008). In contrast, surfactant could stimulate the production of bacteriocins in other studies (Rajaram et al., 2010; Huot et al., 1996).

It was well known that $\mathrm{NaCl}$ is required by many bacteria, for $\mathrm{Na}^{+}$is important to the osmotic pressure to the cells. But $\mathrm{NaCl}$ was not needed for other bacteriocin production (Delgado et al., 2007). In this study, $\mathrm{NaCl}$ played an important part to the growth of the bacteria (Figure 4). But high concentration over $1.41 \mathrm{~g} / \mathrm{l}$ could inhibit the bacteriocin production when glucose concentrations were low. The similar result was found for enterocin P production (Herranz et al., 2001). In contrast, when the concentrations of glucose were high, the effects of changes in $\mathrm{NaCl}$ concentrations were not as marked. It was noteworthy that the interaction of the two factors was obvious when both concentrations were low.

In addition to the nitrogen sources substrates and carbon substrates, salt was also in considered in the present study (Table1, Figure 1). The salt, including $\mathrm{CaCO}_{3}, \mathrm{~K}_{2} \mathrm{HPO}_{4}, \mathrm{KH}_{2} \mathrm{PO}_{4}$, could regulate $\mathrm{pH}$ of the fermentation broth, with substantial effects on biomass production. Previous studies to identify cheaper media focused primarily on nitrogen substrates to some extent (Dominguez et al., 2007; Trinetta et al., 2008; Wiese et al., 2010). However, in the present study, the effects of salt were also considered. The lowest concentration of $\mathrm{CaCO}_{3}$ could stimulate the bacteriocin production, perhaps because it was insoluble, and large amount of could possibly prevent the bacteria production. Also, it seemed that low amount of phosphate could improve the formation of bacteriocins, maybe because the bacteriocin 

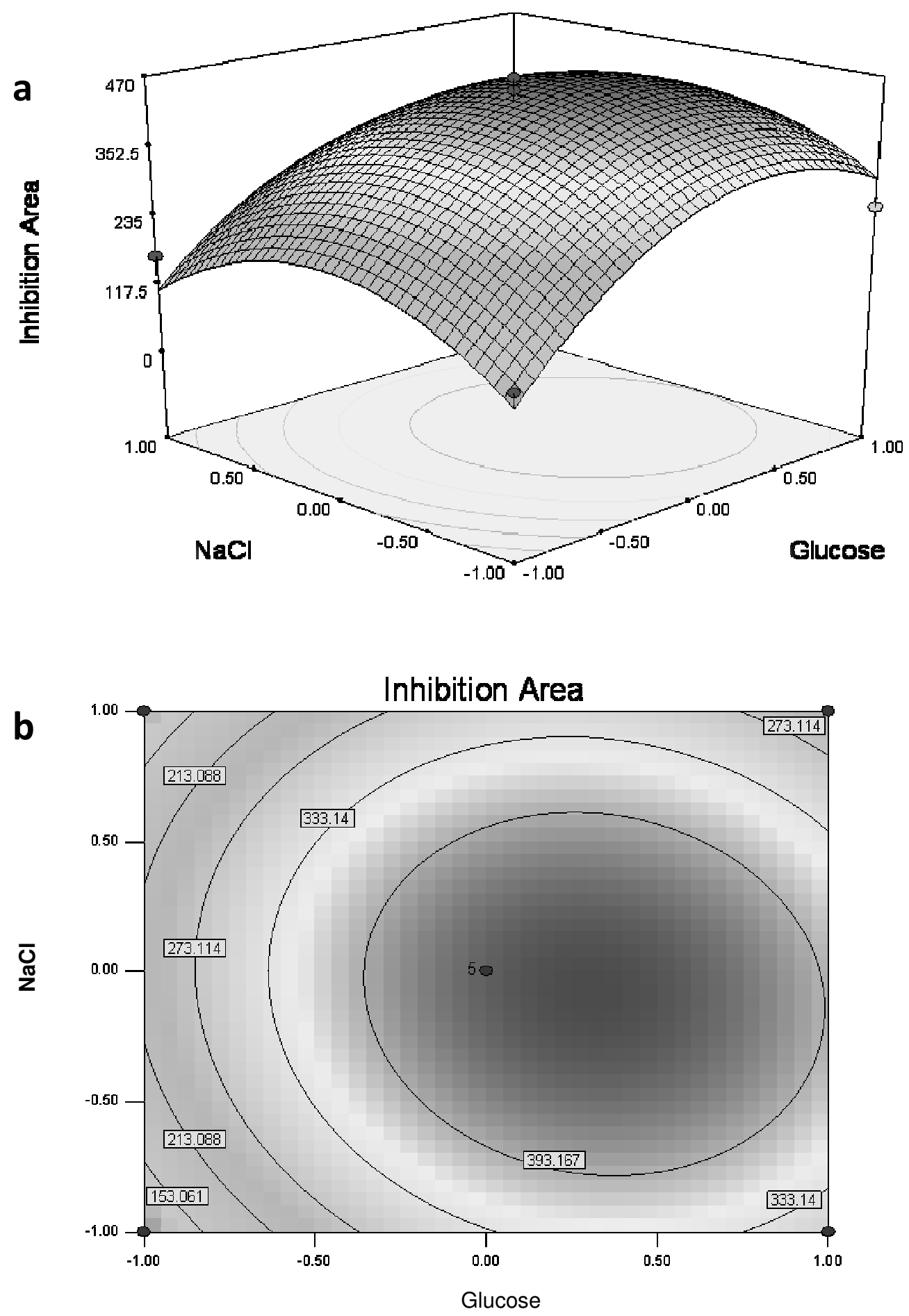

Figure 4. Response surface of production of bacteriocin(inhibition area) by L. plantarum YJG(a) and the contour map of CCD (b). Bacteriocin activity was expressed using inhibition area $\left(\mathrm{mm}^{2}\right)$.

would not be secreted unless $\mathrm{pH}$ reached regular value. The main use of salts here was to improve the amount of the bacteria, indirectly leading to higher bacteriocin production. For the cost of these buffer substances was not high, so it is necessary to apply these buffer substances in industrial processes to prolong the growth period.

In summary, response surface methodology proved to 
be a useful tool to optimize the medium by $L$. plantarum YJG. The concentrations of optimal medium ingredients were as follows: Glucose was $3.6 \mathrm{~g} / \mathrm{l}, \mathrm{NaCl}$ was $1.41 \mathrm{~g} / \mathrm{l}$, $\mathrm{CaCO}_{3}$ was $1 \mathrm{~g} / \mathrm{l}, \mathrm{KH}_{2} \mathrm{PO}_{4}$ was $\mathrm{g} / \mathrm{l}$, soybean peptone was $10.0 \mathrm{~g} / \mathrm{l}$, peptide powder was $10.0 \mathrm{~g} / \mathrm{l}$, yeast extract was $10.0 \mathrm{~g} / \mathrm{l}$, ammonium citrate was $2.0 \mathrm{~g} / \mathrm{l}, \mathrm{MgSO}_{4}$ was 0.575 $\mathrm{g} / \mathrm{l}, \mathrm{MnSO}_{4}$ was $0.14 \mathrm{~g} / \mathrm{l}$. The optimized medium not only allowed the bacteriocin activity increase from 376.36 to $443.85 \mathrm{~mm}^{2}$, but reduced the cost of the medium by $40.6 \%$.

\section{ACKNOWLEDGEMENTS}

This work was supported by Chinese National Programs for High Technology Research and Development (Project No.2006AA10A208) and the National Natural Science Foundation of China (No. 30972124).

\section{REFERENCES}

Anthony T, Rajesh T, Kayalvizhi N, Gunasekaran P (2009). Influence of medium components and fermentation conditions on the production of bacteriocin(s) by Bacillus licheniformis AnBa9. Bioresour. Technol., 100: 872-877.

Cladera-Olivera F, Caron GR, Brandelli A (2004). Bacteriocin production by Bacillus licheniformis strain P40 in cheese whey using response surface methodology. Biochem. Eng. J., 21: 53-58.

Clevelanda J, Montvillea TJ, Nesb IF, Chikindas ML (2001). Bacteriocins: safe, natural antimicrobials for food preservation. Int. J. Food Microbiol., 71: 1-20.

Delgado A, López NAL, Brito D, Peres C, Fevereiro P, GarridoFernández A (2007). Optimum bacteriocin production by Lactobacillus plantarum $17.2 \mathrm{~b}$ requires absence of $\mathrm{NaCl}$ and apparently follows a mixed metabolite kinetics. J. Biotechnol., 130: 193-201.

Dominguez APM, Bizani D, Cladera-Olivera F, Brandelli A (2007). Cerein $8 \mathrm{~A}$ production in soybean protein using response surface methodology. Biochem. Eng. J., 35: 238-243.

Klaenhammer TR (1988). Bacteriocins of lactic acid bacteria. Biochimie., 70: 337-349.

Herranz C, Martínez MJ, Rodríguez JM (2001). Optimization of enterocin $\mathrm{P}$ production by batch fermentation of Enterococcus faecium P13 at constant pH. Appl. Microbiol. Biotechnol., 56: 378383.
Huot E, Barrena-Gonzalez C, Petitdemange H (1996). Tween 80 effect on bacteriocin synthesis by Lactococcus lactis subsp. cremoris J46. Lett. Appl. Microbiol., 22: 307-310.

Hummel W, Schütte H, Kula MR (1983). Large scale production of Dlactate dehydrogenase for the stereospecific reduction of pyruvate and phenylpyruvate. Eur. J. Appl. Microbiol. Biotechnol., 18: 75-85.

Leal-Sánchez MV, Jiménez-Díaz R, Maldonado-Barragán A, GarridoFernández A, Ruiz-Barba JL (2002). Optimization of bacteriocin production by batch fermentation of Lactobacillus plantarum LPCO10. Appl. Environ. Microbiol., 68: 4465-4471.

Li C, Bal JH, Cai ZL, Ouyang F (2002). Optimization of a cultural medium for bacteriocin production by Lactococcus lactis using response surface methodology. J. Biotechnol., 93: 27-34.

Lu Z, Breidt F, Fleming HP, Altermann E, Klaenhammer TR (2003). Isolation and characterization of a Lactobacillus plantarum bacteriophage, $\Phi \mathrm{JL}-1$, from a cucumber fermentation. Int. J. Food Microbiol., 84: 225-235.

Motta AS, Brandelli A (2008). Evaluation of environmental conditions for production of bacteriocin-like substance by Bacillus sp. strain P34 World J. Microbiol. Biotechnol., 24: 641-646.

Rajaram G, Manivasagan P, Thilagavathi B, Saravanakumar A (2010). Purification and characterization of a bacteriocin produced by Lactobacillus lactis isolated from Marine Environment. Adv. J. Food Sci. Technol., 2: 138-144.

Riley MA, Wertz JE (2002). BACTERIOICINS: Evolution, Ecology and Application. Annu. Rev. Microbiol., 56: 117-137.

Trinetta V, Rollini M, Manzoni M (2008). Development of a low cost culture medium for sakacin A production by $L$. sakei. Process Biochem., 43: 1275-1280.

Wiese B, Bru E, Juárez Tomás MS, Nader-Macías MEF (2010). Optimization of low-cost culture media for the production of biomass and bacteriocin by a Urogenital Lactobacillus salivarius strain. Probiotics and Antimicro. Prot., 2: 2-11.

Xie JH, Zhang RJ, Shang CJ, Guo YQ (2009). Isolation and characterization of a bacteriocin produced by an isolated Bacillus subtilis LFB112 that exhibits antimicrobial activity against domestic animal pathogens. Afr. J. Biotechnol., 8: 5611-5619.

Zhou XX, Pan YJ, Wang YB, Li WF (2008). Optimization of medium composition for nisin fermentation with response surface methodology., J. Food Sci., 73: 245-249.

Zhu NH, Zhang RJ, Wu H, Zhang B (2009). Effects of Lactobacillus cultures on growth performance, xanthophyll deposition, and color of the meat and skin of broilers. J. Appl. Poult. Res., 18: 570-578. 